\title{
Recurrent otitis media and pulmonary infiltrates as presenting features in Wegener's granulomatosis
}

\author{
M G Ridley, C S Wolfe, R A Asherson, G R V Hughes
}

Resistant aural, sinus, or nasal inflammation plus unexplained pulmonary infiltrates suggests the diagnosis of Wegener's granulomatosis
St Thomas's Campus, United Medical and Dental Schools of Guy's and St Thomas's Hospitals, London SE1 7EH

M G Ridley, MRCP, senior registrar, department of rheumatology

CS Wolfe, MRCP, registrar, department of rheumatologv

R A Asherson, FACP, honorary consultant physician, lupus arthritis research unit G R V Hughes, FRCP, consultant physician, lupus arthritis research unit

Correspondence to:

DrM G Ridley, Department of Rheumatology, St Peter's Hospital, Chertsev, Surrev KT160PZ.
Systemic vasculitis is not uncommon in hospital practice. A successful outcome, however, depends on prompt diagnosis and treatment, as progression of these conditions may be fulminant, resulting in permanent organ failure, gangrene, or death. Untreated patients with Wegener's granulomatosis had a mean survival of five months and a one year mortality of $82 \%$.' Wegener's granulomatosis has now been transformed to a manageable condition by the use of cyclophosphamide. Awareness of the characteristic patterns of presentation allows a rapid diagnosis to be reached and the avoidance of much unnecessary and expensive investigation. The combination of vasculitic disease of the upper and lower respiratory tracts is characteristic of the disorder." "We report two cases in which the diagnosis of Wegener's granulomatosis was seriously delayed because the relevance of the initial head and neck symptoms to the pulmonary abnormality was not appreciated.

\section{Case 1}

A 59 year old woman presented to her referring hospital with a two month history of ill health, beginning with bilateral suppurative otitis media and deafness resistant to repeated antibiotics Subsequently she experienced intermittent red eves and epistaxes. One month after initial presentation a cough with haemoptysis developed, accompanied by rapid weight loss, intense malaise, and fevers. She had no relevant history and, in particular, no history of ear or sinus problems. Initial investigations showed an erythrocyte sedimentation rate of $110 \mathrm{~mm}$ in the first hour and a neutrophil leucocytosis, and a chest radiograph showed consolidation and collapse of the right middle lobe and "multiple opacities" in the right middle and left lower zones. She was thought to have secondary malignancy and was investigated over the next two weeks with mammography, barium meal and enema examinations; intravenous urography, and abdominal ultrasound, all of which gave normal results. Subsequently attention was refocused on her head and neck symptoms and a nasal mucosal biopsy was performed which showed necrotising granulomas. $\mathrm{Bv}$ this time her renal function, which had been normal at presentation, had deteriorated considerably. A diagnosis of Wegener's granulomatosis was made and treatment begun with oral prednisolone $60 \mathrm{mg}$ a day. She was referred to St Thomas's Hospital.

After transfer examination showed an ill woman who was febrile, anaemic, and deaf, with bilateral episcleritis and crackles at the right base of her chest. Investigations showed a white cell count of $15.6 \times 10^{\prime \prime} / 1$ with a neutrophil leucocytosis, a sedimentation rate of $112 \mathrm{~mm}$ in the first hour, a serum creatinine concentration of $3174 \mathrm{~mol} / \mathrm{l}$, and the abnormal chest $x$ ray appearances as before. Weekly intravenous pulses of cyclophosphamide $7-10 \mathrm{mg} / \mathrm{kg}$ were begun.

Her recovery was complicated by hypertension and congestive cardiac failure, which responded to conventional measures. Over three weeks her general condition and deafness improved and the epistaxes and haemoptysis stopped. Her chest $x$ ray appearances, however, remained abnormal with changing patchy fluffy shadows independent of any change in the physical signs in her chest. These were interpreted as the evanescent shadows of pulmonary vasculitis. On discharge five weeks after admission her white cell count was $6.3 \times 10^{\prime \prime} / 1$ with a lymphopenia of $0.5 \times 10^{\prime \prime} / 1$ (normal $1 \cdot 5-4 \cdot 0 \times 10^{\prime \prime} / 1$ ), sedimentation rate $46 \mathrm{~mm}$ in the first hour, and creatinine concentration $161 \mu \mathrm{mol} / \mathrm{l}$. Outpatient follow up three months later showed improved chest $x$ ray appearances, a white cell count of $6.7 \times 10^{\prime \prime} / 1$, and a sedimentation rate of $40 \mathrm{~mm}$ in the first hour. She had some residual deafness and effort intolerance but was otherwise well, taking cyclophosphamide $100 \mathrm{mg}$ daily and a reducing dose of prednisolone.

\section{Case 2}

A 60 year old woman with a history of rheumatic fever developed deafness in the right ear, which was diagnosed as otitis media. This improved with antibiotics but she was left with right sided facial pain, thought to be sinusitis. Further antibiotics produced little relief and she awoke one morning without vision in her right eye. Examination showed a retinal artery thrombosis and with a sedimentation rate of $70 \mathrm{~mm}$ in the first hour a diagnosis of temporal arteritis was made. High dose oral prednisolone was begun at her referring hospital. One month later she developed breathlessness and oedema. Congestive cardiac failure secondary to mitral stenosis, confirmed by echocardiography, and precipitated by the high dose of steroids was treated conventionally. Shortly afterwards she developed chest pain and haemoptysis. A chest radiograph showed bilateral abnormal shadowing. She was anticoagulated for a presumed pulmonary embolism. Azathioprine was introduced as a steroid sparing agent.

Mouth ulceration, nosebleeds, and weight loss continued. The patient was partially deaf, blind in the right eye, and had increasing malaise. She was referred to St Thomas's Hospital. On transfer examination showed alopecia, mouth ulcers, nasal crusting, conjunctival haemorrhages, blindness in the right eye, fine basal crackles in her chest but no other evidence of cardiac failure, and mild proximal muscle weakness. The sedimentation rate was $66 \mathrm{~mm}$ in the first hour but rose to $123 \mathrm{~mm}$, white cell count $10.9 \times 10^{\prime \prime} / 1$ with a $90 \%$ neutrophil leucocytosis, and $\mathrm{C}$ reactive protein concentration $123 \mathrm{mg} / \mathrm{l}$ (normal $<10 \mathrm{mg} / \mathrm{l}$ ). Nasal mucosal biopsy showed only inflammation, granulation tissue, slough, and pus.

A presumptive diagnosis of Wegener's granulomatosis was made and she was treated with weekly intravenous pulses of cyclophosphamide $10 \mathrm{mg} / \mathrm{kg}$. Recovery was complicated by an episode of septicaemia from a urinary tract infection. She was discharged after five weeks, taking $100 \mathrm{mg}$ cyclophosphamide daily and a reducing dose of prednisolone. Two months later she was clinically much improved with no nasal symptoms, little muscle weakness, and weight gain. 


\section{Discussion}

In both these patients too little attention was paid to the initial symptoms of a recurrently discharging deaf ear, despite the fact that neither patient had any history of chronic aural or sinus problems. We believe that such a history, particularly if unresponsive to standard measures, should alert the clinician to the possibility of a non-infective, inflammatory disease and associated symptoms should be sought. Furthermore, any patient with unexplained pulmonary shadows should be closely questioned about head and neck symptoms and appropriate biopsy samples obtained. Case 2 illustrates the potential pitfalls in interpreting the histological appearances of tissue so obtained. It is not unusual to find necrotic tissue or polymorphs only, and if diagnostic doubt remains a further biopsy sample should be obtained. This is particularly important when there are also abnormalities in lung, as the finding of necrotic tissue may be misinterpreted as necrosis around a tumour-something which, however, is not common. ' The association of haemoptysis with pulmonary shadows proved to be nonembolic, and persistent granulomatous nasal or aural inflammation, or both, is virtually diagnostic of Wegener's granulomatosis.

High dose oral treatment may modify Wegener's granulomatosis but will not suppress disease activity adequately, as shown by case 2 . The use of cyclophosphamide has transformed management of Wegener's granulomatosis into an eminently manage- able disease with worthwhile long term remission during treatment in most cases and, in some, eventual withdrawal of regular cytotoxic treatment. ${ }^{.7} \mathrm{We}$ emphasise that the disease may be far more "limited" in its extent-for instance, affecting only one part of the upper respiratory tract (for example, the laryn $x^{*}$ ) or the orbit." In these circumstances cyclophosphamide is still the preferred drug for treatment and the condition should not be confused with a lethal midline granuloma, which has different biopsy characteristics and responds well to radiotherapy.

We are grateful to Betty Percey for typing the manuscript.

1 Walton EW. Giant-cell granuloma of the respiratory tract (Wegener's granulomatosis ). Br Med 7 1958;ii:265-70.

2 Fauci AS, Wolff SM. Wegener's granulomatosis: studies in eighteen patients and a review of the literature. Medicine (Bultimore) 1973;52:535-61

3 Wolff SM, Fauci AS, Horn RG, Dale DC. Wegener's granulomatosis. Ann Intern Med 1974;81:836-8.

4 Sergent JS, Christian CL. Necrotising vasculitis after acute serous otitis media. Ann Intem Med 1974;81: 195-9.

5 Shah IA, Holstege A, Riede UN. Bioptic diagnosis of Wegener's granulomatosis in the absence of vasculitis and granulomas. Pathol Res Pract 1984;178: $407-12$

6 Hollander D, Manning RT. The use of alkylating agents in the treatment of Wegener's granulomatosis. Ann Interm Med 1967;67:393-8.

7 Fauci AS, Haynes BF, Kat\% P, Wolff SM. Wegener's granulomatosis: prospective clinical and therapeutic experience with 85 patients for 21 years. Aun Intern Med 1983:98:76-85.

8 Hellmann D, Laing T, Petri H, Jacobs J, Crumley R, Stulbarg M. Wegener's granulomatosis: isolated involvement of the trachea and larynx. Ann Rheum Dis 1987;46:628-31

9 Carrington $\mathrm{CB}$, Liebow AA. Limited forms of angiitis and granulomatosis of Wegener's type. Am J Med 1966;41:497-527.

(Accepled 10 May 1988)

\section{BOOKS RECEIVED}

\section{Alternative medicine}

A Health Heart for Lile. The Sicret from the Sica. (: M Shreeve. IPp II2; ligs; 23.99 paperback.) Welling borough: Thorsons, 1988. ISBN borough: Th

Silcnium. I: Trimmer. IPp 96 (2.50) paperback.) Wellingborsugh Thorsons, 1988. ISBN 0-7225-1388-7.

\section{Anaesthesia}

Applicd Niurophosiologn: II'ith Par-

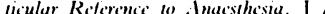
Simpson, W Fitch. IPp 368: figs: $\{35$. London: W'right, 1988. Distributed by Butcrworh. ISBN 0-7236-0707-4.

\section{Cardiology}

Basic and C:limical Cardiology. Viol II. "Drug Therapy in Dilated (ardiomyopathy and Mycearditis." Ld R lingelmeicr, J B O'Connell. Serie cditors $H$ Denolin, H J C: Swan. l'p 304: tigs: $\$ 119.50$. New York Dekker, 1988. ISBN (1)-82+7-7834-X.

\section{Cardiovascular diseases}

Siress and the Heart: Hechamisms, Heasurements, and Managememt. R Futura, 1988. ISBN 0-87993-317-8.

\section{Dermatology}

Ciutuneous Side leffects of Druys. K Bork. Pp +40) colleur plates: $(71.50$. Philadelphia: Saunders, 1988. Distributed hy Harcourt Brace Jowanowich. ISBN (0-0)-(0)12683-5.

\section{Diabetes}

Topisim Renal.Hedicine. "The Kidne and Hypertension in Diabetes Mol litus." lid (:L: Mogensen. Series editor

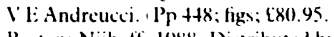
Boston: Niihoff. 1988. Distributed by MTP Press. ISBN (1)-89838-958-5

\section{Endocrinology}

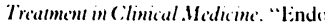
crine and Metabolic Discases." (: M
Feck, C R W Ldwards. Scries editor J L. Reid. (Pp 160; figs; Ł15.95 paperhack.) London: Springer, 1988. ISBN 3-540-19504-1.

Environmental and public health Encironmentul Health Sirries. No 23 "PC.Bs, PCDDSs and PC.DFs: Prevention and Control of Accidental and Environmental Lxposures." Report on two meetings of the World Health Organisation. 1Pp 2+0: figs: paperback price not stat con paperWack, price not stated.) Copenhagen: Office for Europe, 1987.

\section{General Practice}

Practical (icheral Practice: (iuidelines for Logical Afanagememt. A Khot, A Polmear. (Pp 336; 113.95 paperhack.) London: Butterworth, 1988 ISBN 0-407-00473-4.

\section{Haematology}

Blood Diseases in the . Iged. P de Nicola, G (Casale. (1)p 320; figs; 1)M 78. I Stutt gart: Schwer, 1988. ISBN 3-89272 gart.

\section{History of medicine}

Founders of British l'hwsiologn: a Biographical Dictionan, 1820-1885. w J O Connor. IPp 288; 227.50 Manchester: Manchester Universit Press, 1988. ISBN 0-7190-2537-0.

The Histon of the Manugement of Pain. IFrom Early P'rinciples of Presece Pra tice. Ld R D) Mann. I Pp 208; tigs: 139 Carnlorth: Parthenen, 1988. ISBN 0-940813-27-0.

\section{Infection}

P'neumenstis carini P'neumomitis. V'ols 1 and 2. W T Hughes. P Pol 1: 1+4, vol 2: 152; figs; 6139.50 the set. Florida: CRC, Press, 1987. ISBN 0)-8+93-466+-9.

\section{Intensive care}

Clinics in Criticul (Cure Me'dicme. "Cardiopulmonary Critical Care Manage ment." Ld R J Fallat, J M Luce. Series editor I MCA Ledingham. (Pp 240 figs; $\mathfrak{1 2 8 . 5 0 . )}$ New York: (hurchil Livingstone, 1988. ISBN $0-4+3$ 08564-1.

Respiraton Emergencies. E H Sawicka, M A Branthwaite. (Pp 96; figs; 87.95 M A Branthwaite. (Pp 96; figs; $\mathbf{7 7 . 9 5}$
paperback.) London: Butterworth, paperback.) London: Butce
1987. ISBN 0-407-00861-6.

\section{Laboratory medicine}

Basic Microsurgicul Techniques. A Laboraton Manual. C Green, S Simpkin (Pp 48; figs; $\mathfrak{1 7}$ UK, 17.50 overseas, paperback.) Available from the Roval Sexiety of Medicine Services Limited. Publications Department, I Wimpole Street, London W1M $8 \mathrm{AE}$.

Correlative Microscops in Biologr: Instrumentation and Methods. Ed M A Havat. (Pp +56; figs; \$59.) Orlando:
Academic Press, 1987. ISBN 0-12. Academic

\section{Medical ethics}

For the Patient's (jood. The Restoration of Beneficence in Health Care. E D Pellegrino, D C Thomasma. (Pp 256; £22.50.) New York: Oxford University Press, 1988. ISBN 0-19-504319-7.

\section{Medicolegal}

Medical Negligence: a Plaintiffs (iuide. C. J Lewis. Pp 416; 140 hardback. f17.50 paperback.) London: (ass 1988. ISBN hardback 0-71+6-3339-9, paperback 0-7146-4061-1.

\section{Obstetrics and gynaecolog}

Comemporany Obstetrics and (ivnuecologv. Ld G Chamberlain. ( 1 p 446; figs; $\{17.50$ paperback.) London: Butterworth, 1988. ISBN 0-407-01580-9. Principles of Ohstetrics. B M Hibhard. (Pp 832; figs; $\mathcal{E}+5$.) London: Butter worth, 1988. ISBN 0-407-00095-X

Treatment and Prognosis. "Obstetrics and Ginaccology. "Ld G Grudzinskas T' Beedham. Series editor R Hawkins. (Pp 276; : 17.50 paperback.) London: (Pp 276; t 17.50 paperback.) London:
Heinemann, 1988. ISBN 0-43312645-0.
Oncology

Medical Physics Handhooks. Vol 19 "Physical Aspects of Brachytherapy." T J Godden. Series editor J M A Lenihan. (Pp 304; figs; $\mathfrak{1 3 7 . 5 0}$ Lenihan. (Pp 304; figs; 337.50 .
Bristol: Hilger, 1988. ISBN 0-85274 Bristol:
$511-7$.

Palliation in Malignam Disease. J Mosley. (Pp 184; figs; 119.95.) Edinburgh: Churchill Livingstone, 1988. ISBN 0-4+3-03690-X

\section{Ophthalmology}

Neuro-()phthulmologr: a ProblemOriented Approuch, R W Beck, C H Smith. (Pp 288; figs and colour plates; 27 paperback. Boston: Litule Brown, 2988 . Druck.) Bown Lithe Brown, 1988. Distributed by Churchill
stone. ISBN 0-316-08651-7.

\section{Paediatrics}

Manual of ('hild Development. Lingam, D $R$ Harvev. (Pp 112 figs; 17.75 paperback.) Edinburgh: Churchill Livingstone, 1988. ISBN 0-443-03784-1.

Paediatric Formulan: First Edition 987. "Children's Doses." (Pp 128; \& paperback; cheques to be made pavable to Lewisham and North Southwark Health Authority). Available from Ms Gillian Bell, Formulary Pharmacist, Guy's Hospital, St Thomas Street, London SEI 9R'T.

\section{Pathology}

Clinicul and Biochemical Anatuss Vol 24. "Monoclonal Antibodies in Diagnostic Immunohistochemistry." Ed M R Wick, G P Siegal. (Pp 672 figs: \$150.) New York: Dekker, 1988 ISBN 0-8247-7838-3.

An Introduction to Neuropathologv J H Adams, D I Graham. (Pp 320 figs; $(29.95$ paperback.) Edinburgh Churchill Livingstone, 1988. ISBN 0-443-01554-6.

\section{Physiology}

Research Topics in P'hysiologv. "Angiorensin and Blood Pressure Regula tion." Ed J W Harding, J W Wright,

R (: Speth, C D Barnes. Series editor C D Barnes. (Pp 256; figs; \$55.) San Diego: Academic Press, 1988. Distributed by Harcourt Brace Jovanovich. ISBN 0-12-324790-X.

Psychiatry

A Secure Base: Clinical Applications of Atlachment Theon. J Bowlby. (Pp 192; 18.95 paperback.) London: Routledge, 1988. ISBN 0-415-00640-6.

\section{Miscellaneous}

Elsevier's Encyclopuedic Dictionary of Medicine. Part B-Anatomy, in five Medictere. Part B-Anatomy, in five 